Journal of the Rubber Research Institute of Sri Lanka, (2005) 87, 23-35

\title{
Nutritional status of rubber growing soils in the Moneragala district
}

\author{
R S Dharmakeerthi*, S N Silva*, A Yakandawala* and W K Jayasinghe** \\ Received 04 January 2006; Accepted 01 June 2006
}

\begin{abstract}
Rubber cultivation is being expanded extensively into non traditional rubber growing areas such as Moneragala district in the intermediate zone of Sri Lanka. This study determines the nutritional status of these soils for the growth of rubber [Hevea brasiliensis (A. Juss.) Muell. Arg.] and the degree of nutrient variability. Soil samples were collected from the surface layers $(0-0.3 \mathrm{~m})$ and the availability of $N, P, K$, and $\mathrm{Mg}$ status and the urease activity were determined. Leaf $N, P, K$, and Mg status in samples collected from Kalutara, Kegalle and Moneragala regions, were also determined to compare the nutritional status of the plants among regions. Soils in the Moneragala region exhibited a very high variability with regard to exchangeable $K$ (23 - 273 ppm) and exchangeable $\mathrm{Mg}(15-346 \mathrm{ppm})$ contents. The urease activity of the soils was very low (7 $\mu \mathrm{g}$ of $\mathrm{NH}_{4}^{+}-\mathrm{N}$ released $\mathrm{g}^{-1} \mathrm{hr}^{-1}$ ) compared to traditional rubber growing areas. This highlights the need to evaluate the agronomic effectiveness of urea as the $N$ fertilizer in rubber growing soils in this region. Leaf $N$ levels in the Moneragala region was significantly low but leaf $\mathrm{Mg}$ levels in all regions were in the high range. The fertilizer requirement of rubber plants could be highly site-specific in this region and therefore the currently used low $K$ fertilizer mixture with a Mg source may not be equally effective in all parts of the region.
\end{abstract}

Key words: intermediate zone, Moneragala, nutrients, rubber growing soils, urease activity

\section{Introduction}

Rubber cultivation is being promoted in non traditional areas in the intermediate zone of Sri Lanka (e.g. Moneragala district) to increase the rubber production in Sri Lanka, to increase the forest cover in the region and also to improve the social status of the poor in these areas. Although it is known that rubber plant can be grown in the intermediate zone of the Moneragala district, various aspects on efficient resource management to obtain the maximum economic benefits is yet to be studied in detail. One important input often been used in rubber plantations to increase the growth and yields of rubber is application of inorganic fertilizers.

* Rubber Research Institute of Sri Lanka, Dartonfield, Agalawatta, Sri Lanka

** Rubber Development Department, Regional Office, Moneragala, Sri Lanka 


\section{Nutritional status of Moneragala rubber growing soils}

Incorrect fertilizer use not only leads to poor crop growth and lower yields, but also could be a threat to the environment. Therefore, there is an urgent need to evaluate the fertilizer requirement of rubber grown in the Moneragala district in order to identify ways and means to increase the fertilizer use efficiency and to minimize the environmental pollution in the region.

Rubber growing soils in the traditional areas have been evaluated for their nutritional status and it is imperative that the application of $\mathrm{N}, \mathrm{P}$, $\mathrm{K}$ and $\mathrm{Mg}$ in correct proportions is essential to obtain optimum yields in these areas. Therefore, different fertilizer mixtures have been formulated for the three broad soil groups in the traditional rubber growing areas (Silva, 1971). Such studies have so far not been conducted for the rubber grown in the Moneragala region. Therefore, fertilizer mixtures formulated for rubber growing soils in the Low country Wet zone (traditional areas) are being applied by the rubber growers in the Moneragala district. Mostly, a urea based NPK fertilizer mixture $(\mathrm{R} / \mathrm{U} / 12: 14: 14)$ is used in this region with a $\mathrm{Mg}$ fertilizer at rates applied to the traditional rubber growing soils.

Rocks from which soils in the Moneragala district has been derived, and their mineralogy are different from that in the traditional rubber growing areas Cooray (1967). Apart from this soil forming factors such as climate and vegetation are also different in the
Moneragala region. This could lead to the formation of different soils in this region. Studying Wet zone and Intermediate zone soils of Sri Lanka, Mapa et al. (1999 and 2005) have classified soils in the Moneragala region into completely different soil series that are having different chemical and physical properties. Therefore, it could be hypothesized that the availability and the requirement of nutrient for Hevea is different under the eco-physiological situations in Moneragala.

Therefore, the objectives of this study were 1). to determine the nutrient status of the rubber growing soils in the intermediate zone of the Moneragala district and to compare it with traditional rubber growing soils 2). to determine the degree of variation in the nutritional status of these soils in order to evaluate the current practice of using a single fertilizer mixture for the entire Moneragala region.

\section{Materials and Methods}

The study was conducted in 1995 in the intermediate zone of the Moneragala district. Efforts were taken to collect soils samples from the existing rubber growing fields as much as possible while covering the entire intermediate zone of the Moneragala district (Fig. 1). Soil samples were collected from two depths (0-0.15 m and $0.15-0.30 \mathrm{~m}$ ) and at the centre of four rubber plants, where applicable. Samples were air-dried and brought to the laboratory for analyses. 


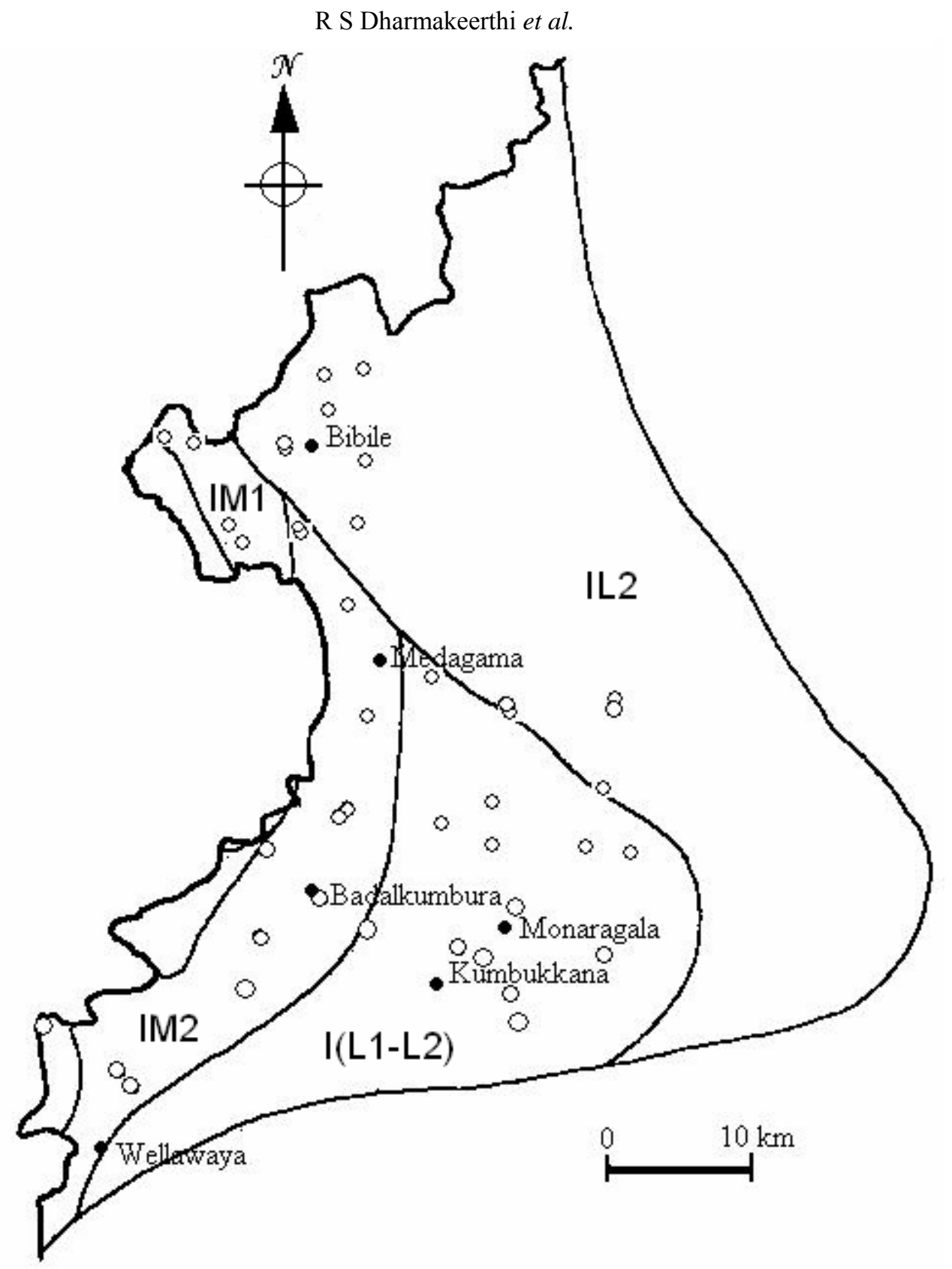

Fig. 1. Map of Moneragala district Intermediate zone showing the approximate distribution of soil sampling points ( $\mathrm{O}$ ) and major agroecological regions 
Nutritional status of Moneragala rubber growing soils

\section{Soil analyses:}

Soil samples were characterized for the basic soil properties and nutrient contents. The $\mathrm{pH}\left(1: 2 \mathrm{CaCl}_{2}\right)$, organic $\mathrm{C}$ (Walkley, 1947), texture (Day, 1965) were determined as the basic soil properties. Nutritional status of the soils was characterized by determining total $\mathrm{N}$ by Se $/ \mathrm{H}_{2} \mathrm{SO}_{4}$ digestion, available $\mathrm{P}$ by $\mathrm{NH}_{4} \mathrm{~F} / \mathrm{HCl}$ extraction, and exchangeable $\mathrm{K}$ and $\mathrm{Mg}$ by ammonium acetate extraction. Nitrogen and $\mathrm{P}$ contents in the extractions were determined colorimetrically using a Technicon II auto analyzer whereas $\mathrm{K}$ and $\mathrm{Mg}$ in the extractions were determined using a GBC atomic absorption spectrophotometer. These methods have been described in detail by Yapa (1983) and Jayasundara (1984). In addition, the urease activity was also determined by a non buffer method (Zantua \& Bremner, 1975) as modified by Dharmakeerthi et al. (1997).

\section{Leaf analyses:}

In order to compare the nutritional status of plants grown in different regions, leaf samples were collected from the clone PB 86 grown in Kalutara, Kegalle and Moneragala regions. Eight fields in each region, established in 1986 or 1987, were sampled. In order to represent the soil surveyed area in the Moneragala district, leaf samples were collected from small holder fields whereas leaf samples from the Kalutara and Kegalle regions were collected from commercial plantations. Leaf sampling was done according to the procedures described by Yogaratnam (1984). After a Kjeldhal digestion procedure the nutrient contents in the extractions were determined using a Technicon II auto analyzer ( $\mathrm{N}, \mathrm{P}$ and $\mathrm{K})$ or $\mathrm{GBC}$ atomic absorption spectrophotometer $(\mathrm{Mg})$.

\section{Statistical procedure:}

Simple statistics of the soil analyses were conducted though SAS statistical package (SAS Institute Inc., 1996). Soil nutrient levels in the intermediate zone of the Moneragala district were compared with those in the traditional rubber growing areas using available literature. ANOVA was conducted for the data from leaf analysis to identify the differences among different soil groups using SAS statistical package (SAS Institute Inc., 1996).

\section{Results and Discussion Basic soil properties}

As expected, $\mathrm{pH}, \mathrm{OC}$ and available nutrient contents were all lower in the $0.15-0.30 \mathrm{~m}$ depth compared to those in the $0-0.15 \mathrm{~m}$ depth. However, for the purpose of comparison of these values with those available in the literature, all values were expressed for the $0-0.30 \mathrm{~m}$ depth by taking the averages of two depths (Table 1). The $\mathrm{pH}$ and sand content had a low variation $(\mathrm{CV}<15 \%)$ whereas clay, silt and OC contents showed a medium variation (CV 15-50\%) according to the guidelines provided by the Warrick (1998). All these properties 
R S Dharmakeerthi et al.

Table 1. Simple statistics of some basic soil properties in the surface $(0-0.30 \mathrm{~m})$ horizon of the soils in Moneragala

\begin{tabular}{|c|c|c|c|c|c|c|c|c|}
\hline Property & $\mathbf{n}$ & Mean & Min & Max & $\begin{array}{r}\text { CV } \\
\%\end{array}$ & Skewness & Kurtosis & $\begin{array}{l}\text { P value of } \\
\text { Shapiro- } \\
\text { Wilk's W test }\end{array}$ \\
\hline $\mathrm{pH} 1: 2 \mathrm{CaCl}_{2}$ & 42 & 5.8 & 5.1 & 6.6 & 5 & -0.190 & 0.569 & 0.444 \\
\hline Sand (\%) & 42 & 78.3 & 69.5 & 86.4 & 6 & 0.023 & -0.662 & 0.512 \\
\hline Silt (\%) & 42 & 7.3 & 0.0 & 15.6 & 49 & 0.474 & 0.579 & 0.057 \\
\hline Clay (\%) & 42 & 14.5 & 10.6 & 21.8 & 16 & 0.810 & 1.536 & 0.098 \\
\hline $\mathrm{OC}(\%)$ & 42 & 0.9 & 0.4 & 1.5 & 29 & 0.310 & -0.180 & 0.912 \\
\hline
\end{tabular}

were normally distributed $(\mathrm{p}<0.05)$ as indicated by the Shapiro-Wilk's W test. Clay content data showed a slight peakedness as indicated by the kurtosis value.

Soils in the Intermediate zone one are not intensively weathered and not subjected to extreme leaching environments as the Wet zone soils. As a result, these soils are not strongly acidic in reaction as is the case in the wet zone soils. The $\mathrm{pH}$ in the studied soils has ranged from 5.1 to 6.6. Soils in the traditional rubber growing areas are strongly acidic to moderately acidic (4.5 to 6.0) which is ideal for the growth of rubber. Therefore, soils with slightly acidic $\mathrm{pH}$ (6.0 to 6.6) could impose a problem on micro nutrient availability if the micronutrient levels are low in these soils. Organic C levels ranged from 0.4 to $1.5 \%$ in these soils indicating a low soil fertility conditions. We observed the soils with eroded surface horizons had the lowest OC levels and these soils were found in the ridge and valley landform in the mid country intermediate zone (Fig. 1). The surface layer of these soils were partially or almost completely eroded leaving only a thin layer of surface soils containing high percentage of decomposing rock fragments. Texture varied from loamy sand to sandy clay loam where clay content ranged from 11 to $22 \%$.

\section{Nutrient availability}

Total $\mathrm{N}$ and available $\mathrm{P}$ showed a medium variation where as all other nutrients had a high variability $(\mathrm{CV}$ $>50 \%$ ). Available $\mathrm{P}$ and exchangeable $\mathrm{K}$ values were not normally distributed $(\mathrm{p}<0.05)$ and skewed to the right. Exchangeable $\mathrm{K}$ values additionally showed a peakedness (Table 2). The distribution of these data within the Moneragala district was studied and then the mean values were compared with those available in the literature for the traditional rubber growing areas (Table 3). Traditional rubber growing soils have been categorized to three broad groups for the fertilizer recommendation purposes based on the differences in the $\mathrm{K}$ and $\mathrm{Mg}$ status in the soil (Silva, 1971). According to him, 
Nutritional status of Moneragala rubber growing soils

Table 2. Simple statistics of the nutritional status of some important macro nutrients and urease activity in the surface $(0-0.30 \mathrm{~m})$ horizon of the soils in Moneragala.

\begin{tabular}{|c|c|c|c|c|c|c|c|c|}
\hline Property & $\mathbf{n}$ & Mean & Min & Max & $\begin{array}{l}\text { CV } \\
\%\end{array}$ & Skewness & Kurtosis & $\begin{array}{l}\text { P value of } \\
\text { Shapiro- } \\
\text { Wilk's W } \\
\text { test }\end{array}$ \\
\hline Total N (\%) & 42 & 0.168 & 0.1 & 0.3 & 21 & 0.290 & 0.017 & 0.476 \\
\hline $\begin{array}{l}\text { Available P } \\
(\mathrm{ppm})\end{array}$ & 42 & 23.1 & 15.9 & 38.6 & 18 & 1.505 & 3.572 & 0.001 \\
\hline $\begin{array}{l}\text { Exchangeable } \\
\mathrm{K} \text { (ppm) }\end{array}$ & 42 & 107.5 & 23.3 & 273.1 & 50 & 1.003 & 0.896 & 0.010 \\
\hline $\begin{array}{l}\text { Exchangeable } \\
\text { Mg (ppm) }\end{array}$ & 42 & 128.7 & 15.2 & 346.2 & 57 & 0.840 & 0.746 & 0.065 \\
\hline $\begin{array}{l}\text { Urease activity } \\
\left(\mu \mathrm{g} \mathrm{NH}_{4}{ }^{-}-\mathrm{N}\right. \\
\left.\text { released } \mathrm{g}^{-1} \mathrm{~h}^{-1}\right)\end{array}$ & 42 & 7.3 & 0.0 & 18.1 & 58 & 0.464 & -0.202 & 0.558 \\
\hline
\end{tabular}

Parambe series soils contain high $\mathrm{K}$ levels compared to all other rubber growing soils and therefore require low $\mathrm{K}$ fertilizer mixtures. Matale series soils have very high $\mathrm{Mg}$ levels and therefore $\mathrm{Mg}$ fertilizers are not being applied to these soils.

Total $\mathrm{N}$ values ranged from 0.10 to $0.25 \%$ with a mean of $0.17 \%$ and this is higher than the values in the traditional rubber growing areas in the wet zone of Sri Lanka but comparable to the values in the Matale series soils in the intermediate zone of Sri Lanka (Silva, 1971). Samarappuli \& Yogaratnam (1995) observed comparable total $\mathrm{N}$ values $(0.18 \%)$ in a rubber plantation with well established leguminous cover crop. Although higher total $\mathrm{N}$ values could benefit the rubber plants grown in Moneragala soils, it depends on the synchrony between the rate of $\mathrm{N}$ released from the decomposition of soil organic matter and the rate of plant $\mathrm{N}$ uptake under the dryer climatic conditions.

Phosphorus is one of the most limiting nutrients in tropical soils due to low $\mathrm{P}$ contents and high $\mathrm{P}$ sorption capacities in these soils. Available P content in the Moneragala soils ranged from 16 to $39 \mathrm{ppm}$ and was comparable to the values recorded for the Agalawatta series soils (Yogaratnam et al., 1984, Kumaragamage et al., 1999). Dissanayake et al. (1992) observed that rubber plants have positively responded to $\mathrm{P}$ application both in a wet zone soil (Boralu series) and an intermediate zone soil (Matale series). However, both of these soils have low available P content compared to that in the Moneragala 
Table 3. Comparison of the mean nutritional status of rubber growing soils in the Moneragala district with the those in the traditional rubber growing soils

\begin{tabular}{|c|c|c|c|c|c|c|c|c|}
\hline \multirow{2}{*}{$\begin{array}{l}\text { Soil series } \\
\text { Boralu }\end{array}$} & \multirow{2}{*}{$\begin{array}{c}\begin{array}{c}\text { Total } \mathbf{N}^{\dagger} \\
\mathbf{( \% )}\end{array} \\
0.060^{\mathrm{A}}\end{array}$} & \multicolumn{2}{|c|}{$\begin{array}{c}\text { Available } \mathbf{P}^{\dagger} \\
\quad(\mathbf{p p m})\end{array}$} & \multicolumn{2}{|c|}{$\begin{array}{c}\text { Exchangeable } K^{\dagger} \\
(\text { ppm) }\end{array}$} & \multicolumn{2}{|c|}{$\begin{array}{c}\text { Exchangeable } \\
\mathbf{M g}^{\dagger} \\
(\mathrm{ppm})\end{array}$} & \multirow{2}{*}{$\begin{array}{c}\begin{array}{c}\text { Urease activity }^{\dagger} \\
\left(\mu \mathrm{g} \mathrm{NH}_{4}^{+}-\mathrm{N} \text { released } \mathrm{g}^{-1}\right. \\
\left.\text { of soil hr } \mathbf{~ h r}^{-1}\right)\end{array} \\
83^{\mathrm{C}}\end{array}$} \\
\hline & & $7.7^{\mathrm{B}}$ & $15^{\mathrm{D}}$ & $18^{\mathrm{B}}$ & $40^{\mathrm{D}}$ & $79^{\mathrm{A}}$ & $17^{\mathrm{D}}$ & \\
\hline Parambe & $0.076^{\mathrm{A}}$ & $2.0^{\mathrm{B}}$ & & $94^{\mathrm{B}}$ & & $250^{\mathrm{A}}$ & & $48^{\mathrm{C}}$ \\
\hline Mawanella & & & $2.5^{\mathrm{D}}$ & & $240^{\mathrm{D}}$ & & $79^{\mathrm{D}}$ & \\
\hline Matale & $0.138^{A}$ & & $2.5^{\mathrm{D}}$ & & $99^{\mathrm{D}}$ & $439^{\mathrm{A}}$ & $322^{\mathrm{D}}$ & $120^{\mathrm{C}}$ \\
\hline Agalawatta & $0.104^{\mathrm{A}}$ & $23.5^{\mathrm{B}}$ & $27.5^{\mathrm{D}}$ & $24^{\mathrm{B}}$ & $40^{\mathrm{D}}$ & $24^{\mathrm{A}}$ & $8^{\mathrm{D}}$ & $82^{\mathrm{C}}$ \\
\hline Homagama & $0.098^{\mathrm{A}}$ & $9.5^{\mathrm{B}}$ & $2.5^{\mathrm{D}}$ & $31^{\mathrm{B}}$ & $25^{\mathrm{D}}$ & $76^{\mathrm{A}}$ & $34^{\mathrm{D}}$ & $81^{\mathrm{C}}$ \\
\hline Rathnapura & $0.060^{\mathrm{A}}$ & & & & & & & $88^{\mathrm{C}}$ \\
\hline Weddagala & & & $2.5^{\mathrm{E}}$ & & $70^{\mathrm{D}}$ & & $22^{\mathrm{D}}$ & \\
\hline Moneragala§ & $0.168^{\mathrm{E}}$ & & & & & & & $7^{\mathrm{E}}$ \\
\hline
\end{tabular}

† - sources: A Silva , 1971; ${ }^{\text {B }}$ Yogaratnam et al., 1984; ${ }^{\mathrm{C}}$ Dharmakeerthi et al., 1997; ${ }^{\mathrm{D}}$ Kumaragamage et al., 1999; ${ }^{\mathrm{E}}$ This study

$\S$ - Monaralgala soils should contain many soil series (Mapa et al., 2005) 
Nutritional status of Moneragala rubber growing soils

soils. Yogaratnam et al. (1984) observed that immature rubber plants grown in Agalawatta series soils, where the available $\mathrm{P}$ content is comparable to Moneragala soils, also have responded with improved growth to $\mathrm{P}$ fertilizer application. Although, it is likely that rubber grown in the Moneragala region would benefit from $\mathrm{P}$ fertilizer application, differences in $\mathrm{P}$ fixation capacities need to be considered in determining the optimum rates.

Exchangeable $\mathrm{K}$ values in Moneragala ranged from 23 to $273 \mathrm{ppm}$ with a mean of $107 \mathrm{ppm}$. The mean value was comparable to that of a Parambe series soils observed by Yogaratnam et al. (1984). Parambe series soils have been categorized as a high $\mathrm{K}$ soil in the traditional rubber growing areas (Silva, 1971). Majority of these soils exhibit a higher K status than group III soils (low $\mathrm{K}$ ) in the traditional rubber growing areas; e.g. Boralu, Homagama and Agalawatta series soils (Kumaragamage et al., 1999). However, we observed a very high variation in the exchangeable $\mathrm{K}$ values in this region which could be attributable to the presence of different soil series in this region (Mapa et al., 2005). Therefore it may be necessary to demarcate areas with very high $\mathrm{K}$ status from the others for efficient nutrient management strategies. Soil samples collected from the IM2 zone (especially in Hingurukaduwa, Ranugalla, Randeniya and Karandagama area) and some soils in the IL2 zone, especially around southern and eastern boarders of the Moneragala hills (i.e. Hulandawa south,
Kiwuleara and Kolonwinna area) and areas around Bibile (e.g. Bokagonna, Kindagolla, Kotagama and Ykunnawa area) recorded high $\mathrm{K}$ values. In traditional areas, plants grown in low and high $\mathrm{K}$ soils have responded differently to $\mathrm{K}$ fertilizer application where growth increase is higher in low $\mathrm{K}$ soils (Yogaratnam et al., 1984). Therefore, for high $\mathrm{K}$ soils in the Moneragala region, a relatively low $\mathrm{K}$ mixture appears to be more effective both economically and agronomically.

Exchangeable $\mathrm{Mg}$ content in these soils varied from 15 to $346 \mathrm{ppm}$ with a mean of $129 \mathrm{ppm}$. The mean exchangeable $\mathrm{Mg}$ value is significantly higher than Boralu, Homagama and Agalawatta series soils but comparable to Mawanella series soils in the traditional rubber growing areas (Kumaragamage et al., 1999). The Mawanella series soils are similar to Parambe series soils classified by Silva et al. (1969). We observed that soils collected from the IM2 zone (especially in Ranugalla, Gamewela, Ambalanpotha and Karandagama area) and some soils in the IL2 zone, especially around northern and eastern boarders of the Moneragala hills (i.e. Ihawa, Thampalawela, Ambalanda and Inawellegama area) had the highest $\mathrm{Mg}$ levels. Application of $\mathrm{Mg}$ fertilizers to high Mg soils could lead to lower yields (Yogaratnam et al., 1984), due to antagonistic effects with $\mathrm{K}$, and therefore the effectiveness of $\mathrm{Mg}$ fertilizers in this region need to be evaluated. 


\section{R S Dharmakeerthi et al.}

\section{Urease activity}

Urea based fertilizer mixtures are being used by the rubber growers in this region. The efficiency of urea as a $\mathrm{N}$ fertilizer depends on the ability of a soil to convert it to plant available forms $\mathrm{NH}_{4}{ }^{+}$or $\mathrm{NO}_{3}{ }^{-}$. Conversion of urea to $\mathrm{NH}_{4}{ }^{+}$is governed by the level of urease activity in the soil (Dharmakeerthi \& Thenabadu, 1996). Urease activity in these soils showed a high variability (CV 58\%) and ranged from 0 to $18.1 \mathrm{~g}$ $\mathrm{NH}_{4}^{+}-\mathrm{N}$ released $\mathrm{g}^{-1} \mathrm{hr}^{-1}$ (Table 2). These values are lower than the lowest values observed in the traditional rubber growing areas in Sri Lanka (Table 3) but comparable with values reported for rubber growing soils in Malaysia (Tan, 1982). Yogaratnam \& Perera (1981) speculated that the higher urease activity in traditional rubber growing areas could in part be due to continuous use of urea as a $\mathrm{N}$ fertilizer which in turn have resulted a proliferation of microorganisms responsible for the release of urease enzyme.

Lower urease activity indicates that the amount of urea need to saturate the urease enzyme is also expected to be low. Therefore, Tan (1982) cautioned that one should avoid application of a high rate of urea at one time to soils with low urease activity as there is a possibility of leaching of unhydrolyzed urea down to lower depths or washed away, especially if heavy torrential rain falls soon after fertilizer application. The $\mathrm{pH}$ of some soils in this region is slightly higher than that in the traditional rubber growing areas. During the urea hydrolysis process the $\mathrm{pH}$ in the soil could increase even further. Although this increase is temporary, the risk of $\mathrm{N}$ loss through ammonia volatilization is greater especially in the high $\mathrm{pH}$ soils (Dharmakeerthi \& Thenabadu, 1996). These possibilities can result in lower efficiency in urea application. Therefore, deep placement of urea in these soils is essential to increase the fertilizer use efficiency of urea, as practiced in the traditional rubber growing areas. These findings indicate the need to evaluate the agronomic effectiveness as well as the environmental concerns of different $\mathrm{N}$ fertilizers when used in rubber growing soils in the Moneragala District.

\section{Plant nutrient status}

Fields in the Moneragala district had been managed by small holders who apply little inorganic fertilizers after first five years, with the termination of subsidy scheme. Farmers in leaf sample collected fields indicated a minimum $\mathrm{N}, \mathrm{P}$ and $\mathrm{K}$ application during the mature phase. Further, a $\mathrm{Mg}$ source had never been applied during this period. Therefore these plants had received very little amount of fertilizer during the last five years. On the other hand leaf sample collected fields from the traditional rubber growing areas were from commercial plantations where RRISL recommended fertilizer application had been carried out during the preceding five years. Therefore one should expect lower leaf nutrient levels in Moneragala region. 
Nutritional status of Moneragala rubber growing soils

Nutrient status of leaf samples collected from three regions showed some significant differences (Table 4). As discussed earlier the nutrient availability in these soils is either comparable or higher than those in the traditional areas. Leaf $\mathrm{N}$ levels were significantly lower in Moneragala than that in the traditional areas. According to the guidelines given by Yogaratnam \& Silva (1977), leaf $\mathrm{N}$ values in Moneragala were in the very low range whereas those in traditional areas were in the low to medium range. Even though the total $\mathrm{N}$ values in Moneragala soils were higher than in Kalutara or Kegalle soils (Table 3), minimum input situation could have resulted lower leaf $\mathrm{N}$ values in Moneragala. Even when fertilizer is applied, a urea based mixture had been used by these farmers. Low urease activity and the higher propensity for volatilization loss of ammonia in these soils could also be responsible for the lower leaf $\mathrm{N}$ values in the Moneragala region.

Leaf $P$ levels were in the medium to high range in Moneragala, medium to very high in Kegalle region, and low to medium in Kalutara region. However, these differences were not statistically significant. Silva (1971) also observed no difference in leaf $\mathrm{P}$ contents among Parambe, Boralu and Agalawatta series although there were some differences in the soil $\mathrm{P}$ availability.

Even though the leaf $\mathrm{K}$ values in Moneragala region is slightly lower than that in Kegalle region, that difference was not statistically significant. Soil $\mathrm{K}$ levels is high in Kegalle region and therefore a low $\mathrm{K}$ fertilizer mixture has been recommended for this region (Silva, 1971). The exchangeable $\mathrm{K}$ values in some regions in Moneragala are comparable to that in Parambe series soils. Therefore, one could hypothesize that a low $\mathrm{K}$ mixture is more efficient in these areas. However, as the higher leaf $\mathrm{K}$ levels helps to counter moisture stress situations (Samarappuli et al, 1993) in dryer areas like Moneragala, plant $\mathrm{K}$ requirement could be high in the Moneragala region. On the other hand the leaf $\mathrm{K}$ status in Moneragala was in the very low range. Therefore, high $\mathrm{K}$ mixtures could continue to be used in this region until the use of a different $\mathrm{K}$ level is substantiated through experimental evidence using different clones suitable for this region.

Table 4. Comparison of the leaf nutrient status of PB 86 clone in three rubber growing regions

\begin{tabular}{|c|c|c|c|c|}
\hline \multirow{2}{*}{ Region } & $\mathbf{N}^{\dagger}$ & $\mathbf{P}^{\dagger}$ & $\mathbf{K}^{\dagger}$ & $\mathbf{M g}^{\dagger}$ \\
\hline & \multicolumn{4}{|c|}{ } \\
\hline Moneragala & $2.40^{\mathrm{B}}$ & $0.233^{\mathrm{A}}$ & $1.08^{\mathrm{A}}$ & $0.25^{\mathrm{A}}$ \\
\hline Kegalle & $3.16^{\mathrm{A}}$ & $0.251^{\mathrm{A}}$ & $1.22^{\mathrm{A}}$ & $0.27^{\mathrm{A}}$ \\
\hline Kalutara & $3.06^{\mathrm{A}}$ & $0.215^{\mathrm{A}}$ & $0.87^{\mathrm{B}}$ & $0.28^{\mathrm{A}}$ \\
\hline
\end{tabular}




\section{R S Dharmakeerthi et al.}

Leaf $\mathrm{Mg}$ levels are not significantly different among regions and these values were in the medium to very high range (Yogaratnam \& Silva, 1977). It is interesting to note that the plants grown in the Moneragala region is capable of maintaining a high leaf $\mathrm{Mg}$ levels even without applying any $\mathrm{Mg}$ fertilizer during the preceding five years. The mean exchangeable $\mathrm{Mg}$ levels in Moneragala soils is higher than that in other two regions and slightly lower than Matale series soils (Table 3) where a Mg fertilizer has not been recommended for plants grown in the Matale region. Yogaratnam et al. (1984) observed that increasing soil $\mathrm{Mg}$ levels by applying higher rates of $\mathrm{Mg}$ could lead to yield decrease in soils where the leaf $\mathrm{Mg}$ content is maintained over $0.25 \%$ without the application of a $\mathrm{Mg}$ fertilizer. Moreover, Weerasooriya \& Yogaratnam (1987) have observed that application of higher levels of $\mathrm{Mg}$ could lead to lower the leaf $\mathrm{K}$ levels which could in turn result poor moisture stress tolerance by the plant. This analysis suggests that application of $\mathrm{Mg}$ fertilizer for rubber plants grown in the Moneragala region could be reduced from the currently applied levels.

\section{Conclusions}

Moneragala is a relatively dryer area than other traditional rubber growing areas. Therefore, the rates of plant growth as well as the nutrient requirement are expected to be different under the agro-ecological situations in the Moneragala region. Soil $\mathrm{pH}$ in this region is slightly higher than in traditional rubber growing soils and availability of some essential macro nutrients is also different. Total $\mathrm{N}$ content in these soils is higher than in traditional rubber growing soils but the urease activity is very low. Therefore, the agronomic effectiveness of different $\mathrm{N}$ fertilizers in the Moneragala region needs to be determined. The mean exchangeable $\mathrm{K}$ and $\mathrm{Mg}$ values in Moneragala soils are high but there is a considerable variation among sites as well. Leaf $\mathrm{Mg}$ levels in the mature plants exhibited a high value even with minimum or no $\mathrm{Mg}$ application during preceding five years. Therefore, either $\mathrm{K}$ requirement or $\mathrm{Mg}$ requirement or both appears to be highly site specific in this region. This study highlights the necessity of careful investigation of $\mathrm{N}$, $\mathrm{P}, \mathrm{K}$ and $\mathrm{Mg}$ fertilizer requirement under different sites in the Moneragala region using clones recommended for dryer areas in order to increase the fertilizer use efficiency while minimizing the environmental pollution.

\section{References}

Bray, R H and Kurtz, L T (1945). Determination of total, organic and available forms of phosphorus in soils. Soil Science 69, 39-45.

Cooray, P G (1967). The Geology of Ceylon. National Museums of Ceylon Publications. pp. 89-124.

Day, R P (1965). Particle fractionation and particle-size analysis. In: Methods of Soil Analysis, Part 1, Agronomy Monograph 9, pp. 562-566 (Eds. C A Black, D D Evans, J L White, L E Ensminger, and F E Clark), ASA and SSSA, Madison, WI. 


\section{Nutritional status of Moneragala rubber growing soils}

Dharmakeerthi, R S, and Thenabadu, M W (1996). Urease activity in soils: A review. Journal of the National Science Council of Sri Lanka 24, 159195.

Dharmakeerthi, R S, Samarappuli, L, Silva, S N, and Yakandawala, A (1997). Urea hydrolyzing potential of the rubber growing soils of Sri Lanka. Journal of the Rubber Research Institute of Sri Lanka 79, 1-10.

Dissanayaka, D M A P, Dissanayaka, T, Gunasekara, R, and Jayasekara S (1992). Clonal differences in rock phosphate utilization by Hevea. Journal of the Rubber Research Institute of Sri Lanka 72, 15-26.

Dissanayaka, D M A P, Dissanayaka, T, Maheepala, Chitra, Gunasekara, R (1994). Role of rock phosphates in the nutrition of immature and mature Hevea. Journal of the Rubber Research Institute of Sri Lanka 74, 42-56.

Jayasundara, H P S (1984). Some aspects of potassium nutrition in Hevea brasiliensis. BSc (Agric) Dissertation, University of Peradeniya. Sri Lanka. pp 77-86.

Kumaragamage, D, Nayakakorala, H B and Vidana Arachchi, L P (1999). Risks and limitations of wet zone soils. In: Soils of the Wet Zone of Sri Lanka, pp. 139159 (Eds. R B Mapa, S Somasiri, and S Nagarajah), Soil Science Society of Sri Lanka.

Mapa R B, Somasiri, S, and Nagarajah S (1999). Soils of the Wet Zone of Sri Lanka, Special Publication No. 1. Soil Science Society of Sri Lanka.

Mapa R B, Dassanayake, A R and Nayakekorale, H B (2005). Soils of the Intermediate Zone of Sri Lanka, Special Publication No. 4. Soil Science Society of Sri Lanka.

Samarappuli, L (2001). Nutrition. In:
Handbook of Rubber, Volume 1, Agronomy, pp. 156-175 (Eds. L M K Tillekaratne and A Nugawela), Rubber Research Institute of Sri Lanka, Agalawatta, Sri Lanka.

Samarappuli, L, and Yogaratnam, N (1995). Rubber plantations as self-sustaining agroforestry systems. Sri Lanka Forester 20, 1-12.

Samarappuli, L, Yogaratnam, N and Hettiarachchi, R (1992). Performance of some RRIC 100 series clones under different soil moisture regimes. Journal of the Rubber Research Institute of Sri Lanka 72, 49-61.

Samarappuli, L, Yogaratnam, N, Karunadasa, P, Mitrasena, $\mathrm{U}$ and Hettiarachchi, R (1993). Role of potassium on growth and water relations of rubber plants. Journal of the Rubber Research Institute of Sri Lanka 73, 37-57.

SAS Institute Inc. (1996). SAS/STAT Procedures Guide for Personal Computers. Release 6.12. SAS Institute Inc. Cary, NC.

Silva, C G (1969). Provisional classification of rubber soils of Ceylon and their relationship to Malayan soils. Quarterly Journal of the Rubber Research Institute of Ceylon 46, 20-29.

Silva, C G (1971). An evaluation of the nutrient status of the rubber growing soils of Ceylon. Quarterly Journal of the Rubber Research Institute of Ceylon 48, 147-159.

Tan, K A (1982). Studies on nitrogen in Malaysian soils. II Urea hydrolysis and transformations. Journal of the Rubber Research Institute of Malaysia 30, 1930.

Warrick, A. W (1998). Spatial variability. In: Environmental Soil Physics pp. 655675 (Ed. D Hillel) Academic Press, USA. 


\section{R S Dharmakeerthi et al.}

Weerasuriya, S M and Yogaratnam, N (1989). Effects of potassium and magnesium on leaf and bark nutrient contents of young Hevea brasiliensis. Journal of the Rubber Research Institute of Sri Lanka 69, 1-20.

Yapa, Y M R (1983). Effects of fertilizers on growth and nutrient uptake of immature rubber. BSc (Agric) Dissertation, University of Ruhuna. Sri Lanka. pp 57-76.

Yogaratnam, N and Silva, P (1977). Use of leaf analysis as a guide to manuring of rubber. Bulletin of the Rubber Research Institute of Sri Lanka 12, 46-50.

Yogaratnam, N, Silva, F P W and Weerasuriya, S M (1984). Recent developments in the nutrition of Hevea in Sri Lanka. In: Proceedings of the International Rubber Conference, September 1984, Colombo, Sri Lanka, Volume 1, Part 1. pp. 207-247. Rubber Research Institute of Sri Lanka, Agalawatta, Sri Lanka.
Yogaratnam, N (1984). Practical aspects of leaf sampling. In: A Practical Guide to Rubber Planting and Processing, pp 109-116 (Eds. A D S Liyanage and O S Peris), Rubber Research Institute of Sri Lanka, Agalawatta, Sri Lanka.

Yogaratnam, N and Perera, A M A (1981). Urea as a nitrogen fertilizer for rubber plantations in Sri Lanka. II Agronomic investigations. Journal of the Rubber Research Institute of Sri Lanka 59, 20 30.

Zantua, M I and Bremner, J M (1975). Comparison of methods of assaying urease activity in soils. Soil Biology \& Biochemistry 7, 291-295.

Address for correspondence: $\operatorname{Dr} \mathrm{R} \quad \mathrm{S}$ Dharmakeerthi, Soils Chemist, Rubber Research Institute of Sri Lanka, Dartonfield, Agalawatta, Sri Lanka.

E-mail: sdharmakeerthi@sltnet.lk. 